Prepublication draft. Full reference: Grigolo, Michele 2016. 'Towards a sociology of the human rights city: focusing on practice', in Barbara Oomen, Martha Davis and Michele Grigolo (eds.) Urban Global Justice: The Rise of Human Rights Cities. Cambridge: Cambridge University Press, pp. 276-293.

\title{
15. TOWARDS A SOCIOLOGY OF THE HUMAN RIGHTS CITY: FOCUSING ON PRACTICE
} Michele Grigolo

This chapter should be considered both a conclusion to a multi-disciplinary research endeavour and an attempt to incorporate some of the key findings and issues of this research into a more coherent sociological understanding of the human rights city as a social construction. Oomen's introductory overview and the more specific studies contributed to this volume show a variety of human rights cities. Overall, the reality for many cities is often a mix of tradition and innovation (see Soohoo in this volume) as well as mismatch between aspirations and actions.

In this chapter, I treat the human rights city as a practice which, while participating in the broader practice of human rights, also departs from it in some important respects. This chapter argues that the specificity of the human rights city emerges at different contact points between 'human rights' and the 'city'. Moving from these premises, the first part of this chapter highlights my approach to the human rights city as practice. The second part explores the relation of coproduction involved in human rights city projects, focusing on the local government and civil society and tensions built into the human rights city binformetween government and justice. The third part explores the human rights city and its relation to the practice of the right to the city, highlighting discontinuities and continuities. The fourth part looks more closely at the institutions of the city that sustain the practice at the implementation level, emphasising the position and role of city employees. The conclusion makes an argument about the added value of sociology to the study of the human rights city, inviting reflexivity and addressing dilemmas and challenges raised by the practice of the human rights city.

\section{THE HUMAN RIGHTS CITY AS PRACTICE}

My notion of the human rights city as practice presupposes that we look at it as something in between an abstract concept that comprises different human rights cities and an idea that social actors produce, discuss and act upon. With an eye on the content of this book, a possible definition of the human rights city is a city which is organised around norms and principles of human rights. ${ }^{1}$ To differing extents, human rights city initiatives show social actors engaged in

\footnotetext{
${ }^{1}$ Koenig (2012) views human rights as an idea that can help organise and guide increasingly diverse urban populations, one with which civil society and local government should both engage with. Smith (2015) views the
} 
having one or more human rights shape urban life and the space of the city by socialising its inhabitants and regulating the conduct of the local population and the local government, and the relation between them.

This definition departs from those provided in this volume and elsewhere insofar as it is not centred in the local government but the city and it does not tie the notion of human rights to 'international human rights' (see the introduction by Oomen) or 'human rights as laid down in international treaties' (see Oomen and Van den Berg 2014: 163). On the one hand, my definition acknowledges the possibility that a human rights city might be pursued outside the local government, and without the intervention of the local government, or with a more external support. On the other, I keep open the possibility that the actors involved in the human rights city may define and articulate human rights in ways that differ from international norms and principles. Exploring the human rights city as practice, then, requires that we look into the different processes whereby social actors collaborate and compete to define human rights and their meaning and act towards establishing these human rights as guiding and regulatory principles of urban life and space.

The variety of ways in which social actors engage with human rights can be understood as the consequences of the different discourses that, in the practice itself, the actors produce in order to support and contest certain meanings of human rights. These 'discourses' of human rights are intended here in a Foucauldian, post-structuralist sense: as statements of truth about human rights which are generated by the practice while at the same time constituting it, by framing and orienting it. Each discourse is also a particular knowledge of human rights, which compete with other knowledge and the alternative versions of human rights this produces. This process does not take place in a vacuum: to echo Goodale (2007: 24), 'the practice of human rights is always embedded in preexisting relations of meaning and production'. In short, it is itself the product of a particular social context within which human rights are understood and negotiated.

At this point, we can start making sense of the continuities and discontinuities between the broader practice of human rights and the practice of the human rights city, understanding the latter as being embedded in the former and therefore obviously shaped by pre-existing meanings and discourses of human rights circulating in the practice. Human rights as we know them from the international regime and state practice are the set of notions and institutions within which the human rights city is constructed and which influence the human rights city to the extent that the actors involved in it take this knowledge of human rights as a given reality. From the

more specific 'goal' of promoting 'universal' human rights as the principle around which the city should be organised. In my definition this goal is viewed as part of the broader process that shape the practice of the human rights city in collaboration and competition with other possible goals. 
Bourdieusian viewpoint advocated by Rask Madsen (2013), it is possible to suggest that this knowledge of human rights is produced in the 'field' of human rights in the context of the relation of collaboration and competition between some core actors, i.e. international organisations, states and the law (via the intervention of lawyers and other judicial and legal actors). This knowledge of human rights is itself a powerful discourse, structuring our own understanding and use of human rights (O’Byrne 2012). This discourse tells us that human rights are universal and equal rights that are primarily individual; they are defined primarily by the law; they are justiciable civil and political rights and programmatic economic, social and cultural rights; they are expanding towards a new generation of rights.

Eventually, what makes the difference between this practice of human rights and the human rights city is, quite simply, the city. What many chapters of this book offer are digressions from the dominant practice and elements of a practice of human rights redefined around the city and primarily, but not exclusively, in the city. What I wish to emphasise here is a sense of agency and the possibility that the production of new meaning of human rights is instigated by the relation of proximity between human rights and the city (Grigolo 2010 and 2011; see also Darling's notion of the urbanisation in this volume). At the same time, it must be clear that the human rights city is contended by different actors and discourses, as different actors understand, interpret, justify and promote the relation between human rights and the city in different ways. These actors 'struggle' with the city in order to make sense of it from a human rights viewpoint. In many respects, these actors also 'struggle' (with uneven power) to impose their version of human rights on other actors, driven by distinct interest in, and emotional attachments to, particular human rights and the form they should take in the city.

As this book shows and the next section will further elucidate, many of the actors involved in the human rights city are also the actors that dominate the field of human rights and are not necessarily located inside the city. At the same time, the human rights city is primarily the outcome of the engagement with human rights of civil society and local government actors, both inside and outside their city. They lead local projects about human rights and much of what they export about the human rights city is itself a reflection of their own practice. Still, many chapters of this book remain fundamentally concerned with how the local government engages with human rights and/or, from a normative viewpoint, should engage. In this respect, two types of local government engagements with human rights are highlighted in this volume, which in the practice of the human rights city are often intertwined. One regards the mobilisation of discourse and claims about the human rights city, including the human rights of cities, through which actors inside local governments aim to establish their own vision and meaning of the human rights city.

The other regards the institutionalisation of human rights within the local government. It is within processes of institutionalisation that we can see what the grand statements embraced 
and promoted by cities produce at the implementation level. From a sociological angle, the point here is to understand 'what are the means whereby a claim moves from the initial engagement with a rights issue, through the process of garnering support, to formal recognition and finally institutionalisation' (Morris 2006: 242). At this level, mayors may matter less than those city employees and bureaucrats involved in the 'messy realities of interpretation and implementation' (Hynes et al. 2010: 813). Needless to say, this is a crucial level if we want to understand the capacity of particular discourses to generate the kind of action and intervention that they prefigure and prescribe.

Many chapters of this book cast different lights on the engagement of the local government with human rights. While the authors in this volume tend to take a positive view of human rights cities, they nevertheless suggest that it also poses a number of 'challenges'. These challenges evoke the paradox whereby public powers are at the same time guarantors and violators of human rights. From the sociological angle, the question is often the manipulation and domestication of human rights by public authorities at the level of meaning, for purposes that are at odd with their universal and egalitarian aspirations, e.g. justifying war. As Stammers (2009) notes, institutionalisation is the more or less implicit and somewhat necessary horizon of any process of mobilisation of human rights. However, it is a process that tends to constrain more emancipatory and social movement-driven notions of human rights. Ruzza (2006) shows that while human rights are increasingly popular also among politicians and bureaucrats, especially on the progressive side of the political spectrum, institutionalisation often implies that ideas oriented towards emancipation, e.g. anti-racism, are redefined within particular organisational cultures in ways that leave activists at best only partly satisfied.

In this respect, what we need to consider in the case of cities is also the broader social and economic structure within which human rights are produced nowadays: a capitalist society and neo-liberal economy which, to differing degrees of intensity, are becoming as global as the idea of human rights. This structure poses crucial 'limits' and 'dilemmas' to cities and their local governments regarding the priority to be given to certain agendas, particularly the economic one (Peterson 1981, Keating 1991, but see also Graham et al. in this volume). As the organisation of the state government is discursively replaced by the multi-level governance of a number of issues that are often recast as urban (Le Galès 2002), 'urban governance' becomes the tool for governing territory and the local government is encouraged to play the role of a mediator between the interests of different stakeholders in particular policy areas. What are (perceived as) powerful economic priorities, however, are hardly neglected by local governments, especially when core urban issues such as planning and development are at stake. In this picture, the human rights city and the neo-liberal city are in a relation of competition and collateralism. In this kind of city, 'human rights' may be constructed both in conjunction with and in opposition, to issues such as 
'migration', 'security', 'social policy' and, last but not least, 'development'. These issues are more explicitly raised by authors addressing the right to the city (García Chueca, Darling, Starl and Sánchez Rodríguez in this volume) and throw up the question of the extent to which human rights can offer a site of resistance to the interest of economic actors in the city.

In this picture, the law plays a crucial part, beginning from the obvious fact that historically the law has been the privileged site for negotiating rights and their meaning. Several contributions to this book (see in particular Davis, Starl and Pestova) highlight the legal dimension of the human rights city and how it combines with political commitment and engagement. From a legal and socio-legal viewpoint it is possible to think of the city as a 'level' and 'context' of human rights implementation (Grigolo 2010: 897, Grigolo 2011): the city is embedded in a vertical and hierarchical system of legal relations (see also Oomen and and Soohoo in this volume) while at the same time being the space where the laws of these levels (including the law of the city) converge to regulate particular issues and groups. It is from this dual perspective that the relation between the city and the law of human rights, as well as the extent to which the latter is a constraint or an opportunity for the former (the question of 'legalisation' evoked by Darling in this volume), need to be understood and analysed. From a sociological perspective fully aware of the importance of the law, the question becomes how in particular local human rights institutions employ rights discourses and legal strategies to intervene on particular issues, and the extent to which these processes are aimed at emancipating or disciplining individuals and particular groups of people.

What we have said so far has important implications for understanding the kind of justice that the human rights city delivers. In fact: justice itself is a social construction, generated by the practice. Justice is defined and substantiated out of the interplay of different goals and meanings engaged in the human rights city and the extent to which human rights guide urban life as opposed to, but also often in an ambiguous relation with, other principles. The social and economic structure as well as cultural environments within which the human rights city is produced have important consequences for the kind of 'injustice' that exists in today's cities, with different issues emerging in particular cities at the centre and periphery of capitalism. The kind of justice human rights can deliver depends on the way in which different actors connect the 'global' and the 'urban': how human rights are mobilised, redefined and constructed strategically against the background of structural forces within the spaces of engagement, resistance and opposition available within the city and the local government. In the next section we begin to see in greater detail who these actors are and how they participate in the human rights city. 


\section{MAKING THE HUMAN RIGHTS CITY}

Like other practices of human rights, the human rights city can be understood sociologically as a process of collaboration and competition between different social actors and therefore, ultimately, a co-production, originated in the area of progressive politics. Human rights cities are mainly cities with progressive local traditions, politics and leadership, which human rights redefine in more globally intelligible terms. In this section I look at these actors, their interactions, and the crucial relation of co-production between civil society and local government.

What makes the human rights city is a web of formal and informal networks that include international and national governmental and non-governmental organisations as well as other cities, as shown in different chapters in this volume. These networks operate, in a sense, as a structuring force on local actors that (wish to) do human rights, reinforcing and promoting existing practices; however, to the extent that they stimulate reflections on, and diffuse, new practices, they are also sites of agency and new engagements.

The net result is both an increased visibility of human rights cities inside the field of human rights and also the overlapping between initiatives and networks. And yet, actors in this network do have different ideas of what human rights cities and local government engagements should look like. In fact, these actors end up in a sort of competition to have cities engage with human rights in certain ways. Researchers (including those who are contributing to this volume and constructing the human rights city from their own disciplinary perspectives) and their academic departments, practitioners, activists and more general 'experts' may have a notion of human rights city which is tied to their particular experience (as researchers and practitioners) and locality, more than the necessarily abstract formulas and standardised plans promoted by international organisations.

Moreover, international organisations do intervene in the human rights city conversation in the pursuit of their own mandate and supporting a concept of human rights influenced by their own organisational (often legal) culture. More generally, international governmental organisations proactively seek to have cities participate in the multi-level governance of particular rights that fall within their own mandate, as cities are perceived as crucial allies for the pursuit of that right and mandate. For example, UNESCO's and US mayors' plans against racism (see Starl and Kamuf Ward in this volume) can be understood in the context of 'geopolitical events' that have emphasised the connection between anti-racism and urban policy (Ruzza 2006: 115). At the same time, these international actors remain concerned about incorporating cities into a practice of human rights that is still very much centred on the state and the law. The joinedup governance project and tool-kit promoted by the Fundamental Rights Agency of the European Union is an example of this. Local governments, in turn, may be more than happy to collaborate 
in this kind of project and may see collaboration with international organisation as an opportunity to position themselves in international political arenas and economic markets (Immler and Sakkers 2014).

As typical of the broader practice of human rights, civil society actors play a crucial role in the generation and diffusion of new ideas about doing human rights in cities and, in some countries, 'bringing human rights home' (Soohoo, Albisa and Davis 2008, Oomen 2014). They can emphasise the importance of cities within a process that continues to focus mainly on the state, such as peace building (Smith 2015). However, it is important to remain aware of the differences that exist between these actors and of the fact that these differences can enrich but also undermine their actions and campaigns (Merry et al 2010). PDHRE's Human Rights Cities program emphasises the importance of building a constituency for the human rights city more than the commitment of the local government. Amnesty International is historically more inclined towards institutional politics. Activist lawyers may be sceptical of engagements that are not backed by a procedure that secures accountability and justiciability (see Davis and Frate in this volume).

Initiatives that promote a shift of human rights practice, however, have also received fundamental contributions from local governments. The European Charter for the Safeguarding of Human Rights in the City (ECHRC) is an obvious example (see Grigolo 2009: 118-133 and Oomen, García Chueca and Kamuf Ward in this volume). Some local governments and mayors engage more proactively than others and come to exercise a more visible influence on the practice of other cities. The role played by the Barcelona government at the transnational and regional level is captured well by García Chueca in this volume.

Within this broad transfer of knowledge, however, what drives the process of making human rights in individual cities is a relation of co-production, marked by collaboration and competition, between civil society and local government. A starting point for thinking about this is Van den Berg's distinction in this volume between bottom-up and top-down approaches. This distinction aims to capture the centrality of civil society (bottom-up) or the local government (top-down) in any human rights initiative in the city. However, Van den Berg herself finds it difficult to unravel who does what in the human rights city. This challenge is often due to the dense quality of the political and social relations inside the progressive milieus within which human rights are built (in cities and increasingly transnationally). Whether the initiative starts from civil society or the local government, however, one will usually see that, at some point, actors in either or both camps will seek each other's engagement, as they all become interested in opening a space of institutionalisation of human rights within the local government.

It should be clear that once human rights start a process of institutionalisation, the local government will acquire a stronger control over them. In this space of institutionalisation certain 
actors more or less inclined towards 'collaborative activism' (see Van den Berg in this volume) can try to push and negotiate more or less particular notions of human rights. And yet, we can say along with Ruzza (2006), that the process of defining and articulating a certain notion of human rights will inevitably be influenced not only by the interests and visions of the local government, but also its more or less progressive organisational culture. The argument could be made, based on previous research and this book, that local governments appropriate and use human rights from the viewpoint of how much they enhance their capacity to govern the city (Grigolo 2010; see also Kamuf Ward in this volume). This approach to human rights explains why especially progressive local governments may take the opportunity offered by human rights to open a channel of communication with local civil society, establishing forms of collaboration that may not be immune to the classical co-option taking place in any process of institutionalisation (see Stammers 2009).

In the end, we can suggest that due to the co-production between civil society and local government, a relation and tension is built (also) into the human rights city between, on the one hand, the imperative of 'justice', to which civil society concerned about human rights may be more sensitive, and on the other, the logics and constraints of 'government' (including 'governance') that guide the local government and necessarily inform any process of institutionalisation. This tension can obviously be solved in context, reaching different compromises between justice and government. Yet these compromises will obviously be somewhat unstable, especially when implicit limits the actors involved consider non-negotiable are surpassed. For example, when constraints of institutional politics are disrespected, the local governments and mayors in particular, may step back.

In the next section we explore further the tension between justice and government, looking into the differences and continuities between human rights and the right to the city.

\section{THE HUMAN RIGHTS CITY AND THE RIGHT TO THE CITY}

A number of authors in this volume address and problematise the relation between the human rights city and the right to the city. In this section, I argue that while in principle the human rights city and the right to the city are distinct practices, they are also collateral to the extent that are both produced out of certain readings of the relation between human rights and the city and they actually discursively engage one with the other, suggesting the possibility of a combination between the practices.

As a starting point, the argument can be made that the human rights city and the right to the city are practices different one from the other.

The question of the difference should, in my opinion, be explained by the fact that we are talking here of different kinds of rights informing the two practices and how these rights speak 
differently to issues of government and justice. The basic distinction is that between human rights and the right to the city, not the human rights city and the right to the city. Human rights, whether of the state or of the city, are built on the fundamental discursive premises that 'government' is responsible for delivering human rights, which implies that government exercises control over justice. Delivery of justice takes place in the context of the relation between government as the duty-bearer and people as rights-holders around a variety of issues/rights.

In the human rights city, government continues to be central, albeit to differing extents depending on the initiative. Government is definitely more central in the ECHRC and the Montreal Charter of Rights and Responsibilities than PDHRE's Human Rights City. This has to do also with 'charters' being initiatives heavily sponsored by municipalities, as opposed to PDHRE's Human Rights Cities. ${ }^{2}$ In the charters the replacement of the state with the local government is more evident and is sustained by legal discourse. By imitating the language and form in which human rights are produced in the international human rights regime, the local government suggests that the actor that should be addressed by that regime and around which the practice of human rights should be centred is the local government. By replacing the state in that the international human rights regime, local governments carve out their own space in that regime and 'steal the show' from the state. They do it, it should be clear, in a way that gives them all the symbolic advantages without the burden of being primarily responsible to deliver human rights.

With that said, it is significant that much new human rights meaning generated by the human rights city revolves around the space, use, activities and inhabitants of the city, in ways that continuously evoke the right to the city, its conceptualisation in the literature and its practice (see Sánchez Rodríguez in this volume; Purcell 2002). Article I of the ECHRC (UCLG 2012) actually provides for the right to the city. Human rights further incorporate the right to the city in its universal and egalitarian aspirations in Article II of the ECHRC, which provides that the 'Principle of Equality of Rights and Non-Discrimination' for all the 'inhabitants' of the city. Both the ECHRC and the Montreal Charter, then, provide for urban rights of a third generation type, focused on post-materialist issues such as environment and the more general quality of life in the city. As García Chueca and Frate show in their chapters, both charters provide for the same rights to 'leisure' and 'development', although development is also 'harmonious' (in the ECHRC) and 'sustainable' (in the Montreal Charter). Other rights concern 'movement', 'tranquility', 'mobility' (García Chueca), and 'sports', ‘security' and 'high quality municipal services' (Frate).

\footnotetext{
${ }^{2}$ However, even PDHRE's Human Rights City presupposes a commitment of the local government. It is actually quite revealing that this commitment is prescribed by PDHRE and it is accordingly taken by some as a precondition for 'becoming' a human rights city (see Neubeck in this volume).
} 
More classical rights are not missing, at the same time being redefined from the viewpoint of local government competences and priorities. Emphasis is placed on economic, social and cultural rights, which send a message of 'social' as opposed to purely 'liberal' justice'. Some rights evoke the right to the city in a more straightforward manner. Frate and Neubeck present the right to housing in Montreal and Eugene, respectively, as somewhat compensating for the lack of a state recognition of this right. Another example provided by Frate is the recognition in the Montreal Charter of the right to water, before the same right was recognised as a human right also by Canada (see also Pestova in this volume), hinting at the centrality of local governments in the preservation and promotion of the commons and the relation between the commons and human rights (Fantini 2012, Chiu 2013).

This does not imply, of course, that one practice mirrors the other. The right to the city maintains a connection with more radical social movements that is fairly absent in the mainstream of the human rights city practice. To the extent that the local government and its engagement with human rights remains central but is also perceived as fundamental in the human rights city camp, the human rights city itself will tend to be a matter of negotiating rights and accepting compromises with the local government about the kind of justice it delivers. The right to the city, at least in the way in which it is formulated and produced in Mexico City (Sánchez Rodríguez in this volume) does not exclude human rights from the picture. However, by introducing the notion of the 'social function' of property, the Mexico City Charter tends to isolate the provision of human rights, especially those of a more urban and spatial quality, and the right to housing, from a purely liberal notion of right to property.

In a sense, in the right to the city, 'justice' comes before 'government', putting government action and its human rights, in the perspective of delivering a certain justice: preserving the collective nature and quality of the city space, and putting local residents and their needs and uses vis-à-vis the space of the city, at the centre of the city and human rights. Eventually, this should be achieved through forms of participation, around in particular planning and housing, that are not pre-empted by powerful economic interests. More than mainstream notions of urban governance, or non-binding forms of consultation such as those provided by the Montreal Charter, we are talking here of projects for the city aimed at 'empowering democracy' (Fung and Olin Wright 2003) or, from a more antagonist perspective, 'recapturing democracy' (Purcell 2008).

Eventually, what distinguishes the two practices may be the way in which they not only read human rights through the city but also the other way around: how cities are redefined through human rights, and the kind of discourse about the city that human rights sustain. The production of new meaning of human rights goes together with the production of new meaning of the city. The image of the city sustained by human rights charters is of progressivism and 
tolerance, of a place where it is desirable and safe to live and is secured by a local government. This human rights discourse on the city will be resisted from a right to the city viewpoint to the extent that it conceals and contradicts the social, political and economic reality of the city. It will be contested to the extent that it is a brand and itself the product of the kind of neo-liberal city that activists contest, part of that 'moral urbanism' that Darling discusses in this volume.

Despite the core differences between the practices of the human rights city and the right to the city, the constructionist viewpoint advocated here warns against the risk of essentialising and reifying of these two practices. It leaves open the possibility of a kind of 'constructive reconstruction' and strategic resistance in between the two practices to the extent that the social forces that sustain the human rights city and the right to the city, inside and outside the local government, may well share the common social, political and legal space of the city and sometimes the same vision of a just city. On such premises alliances should be forged capable of mobilising the discourse and law of human rights in ways that are more strategically oriented towards justice. Seen from this perspective, the chances of success and failure may be less due to the inherent differences between the human rights and the right to the city than the broader social and economic structures in which these practices are developed. From this angle, it becomes relevant where either practice, or a combination of them, is located in the geography of neoliberal capitalism, the power of civil society to promote a 'more progressive' vision of and agenda for the city, and the degree to which the local government is sensitive to and receptive of this agenda.

\section{THE HUMAN RIGHTS INSTITUTIONS OF THE CITY}

The question of implementation that many chapters of this book deal with has to be recast from the viewpoint of the definition of human rights city adopted here, as action undertaken to diffuse and impose human rights as the regulatory principles and norms of the city, inside and outside the local government. This process is sustained by a variety of institutions which are sometimes named and provided for in the charters, motions and statements that define the human rights city. The human rights institutions of the city comprise the procedures and organisations that are expected to place human rights at the centre of the social and political life of the city. In this section I try to show how this process is again influenced by the dominant practice of human rights while also revising that practice. As part of this process, I will also show that new meaning of human rights is generated and reinforced along the different trajectories towards which human rights are pushed. Finally, this section exposes some limits to the diffusion of the human rights city and the right to the city, while suggesting that the law can support the development of both practices in particular cities. 
Different chapters in this book show that there is often a dedicated human rights body behind any process that supports the diffusion of human rights in the city. Examples in this book include the Municipal Human Rights Council in Graz (see Starl in this volume), the Human Rights Commission in Eugene (see Neubeck in this volume), the Human Rights Commission in Mexico City (see Sánchez Rodriguez in this volume) and the Ombudsman in Montreal These bodies clearly operate from within the local government, or in association with it, in order to perform a variety of functions which can be grouped under two broad lines of actions: 1) educating people on human rights in general (through conferences, human rights days, etc.) or specific training (to local government staff, students, workers, etc.); and 2) remedying what are seen and categorised as threats to human rights, via interventions on particular cases or complaints, relying on different legal powers and competences. These bodies operate with methodologies typical of the practice and a classical liberal approach to human rights.

Dedicated bodies, e.g., commissions as well as committees and task forces, can also support particular initiatives related to the mainstreaming of one or more human rights within the local government, with a mandate to coordinate the mainstreaming of human rights across different departments and policy sectors. The mainstreaming approach has been imported from gender policy and has been experimented with some success in San Francisco's implementation of its CEDAW ordinance (Lozner 2004). A similar approach can be found in Eugene and is sustained by the Human Rights Commission. As Neubeck in this volume shows, the scope of this kind of intervention is to change the organisational cultures inside the local government and particular city departments.

Not surprisingly, the institutional infrastructure of the right to the city seems more complex and less immediately recognisable in pre-existing models. Sánchez Rodríguez in this volume shows how the 'Full exercise of human rights' in the right to the city envisioned in Mexico City is only one of the six 'foundations' of the right to the city, and how the Human Rights Commission of Mexico City is clearly part of the right to the city. Human rights, however, share the space with 'the sustainable and responsible management of the commons' and the overall 'democratic' quality of the city, which includes its 'management'. These foundations combine in turn with six 'principles' to sustain the right to the city. The right to the city itself is a 'construction', out of 'effective and extensive participation'. In line with Sánchez Rodríguez's premise that the right to the city is a construction, the practice of the right to the city seems organised in a way that leaves open the possibility of different trajectories.

There are at least two important lessons one can extract from looking into these institutions and their work. One is that they are involved in the production of new meaning of human rights, and by that I mean human rights beyond those formally enunciated and proclaimed in official statements and laws. There exists a micro-level of construction and reconstruction of 
human rights, where city employees and bureaucrats' own engagement with human rights does not simply 'implement' or 'translate' the officially recognised human rights of the statements. City employees re-work and redefine human rights in the context of their daily activities and the concrete issues they have to deal with and the kind of 'discretion' (Lipsky 2010) that they exercise in the conduct of their operations. Ife (2014: 204-214) argues, for example, that social workers construct human rights in ways that are both deductive but also inductive: they are driven by the idea of complying with human rights and often at the same time engage human rights discursively in the framing and solution of a concrete situation. The city then is also involved in the production of this meaning, but at a level of the practice of city employees and the many decision they take on which policy implementation is fundamentally dependent on. Of course, there is no guarantee that these employee interventions are always desirable or in line with established human rights standards. City employees can make decisions and allocate resources in ways that reinforce, for example racism in the field of housing (Sala Pala 2010).

This book presents evidence of this micro-level construction of meaning and the context in which this is generated. Bodies that treat complaints, for example, are pushed into dealing with cases that may not have direct implications for the kind of human rights mandate that inform their mandate. The Montreal Ombudsman ${ }^{3}$ acknowledges that of the many topics raised by the complaints she receives on a regular basis 'very few requests are "purely Charter" files' (see Frate in this volume). In fact, many topics concern issues she was already dealing with under the bylaw regulating the activities and competences of the Ombudsman. And yet, by becoming part of human rights implementation, the scope of the Charter, its human rights and the work of the Ombudsman will tend to be stretched in an effort to comprehend and deal with these issues. The study of complaints of the Barcelona Office for Non-Discrimination reveals a similar stretching of meaning driven by the practice, e.g. in relation to the rights of migrants (Grigolo 2010).

One more or less explicit scope of any mainstreaming of human rights, then, is precisely about controlling the use of human rights by city employees and the deductive and inductive dynamics involved. There are obvious tensions here between, on the one hand, controlling meaning in order to make sure that it does not deviate from some content (lawyers may be especially concerned about safeguarding the legal content of human rights, hence the warning coming from Frate in this volume about avoiding 'creative interpretations' of human rights); and, on the other, encouraging new meaning that can help make sense of particular situations (hence the invitation coming from the case of Eugene presented by Neubeck in this volume, 'to think outside of the box'). Both dynamics are actually involved in the mainstreaming of human rights

\footnotetext{
3 I am using the term 'Ombudsman' and not the more neutral 'Ombudsperson' in order to reflect the title used in Montreal for this position.
} 
in Eugene, a city where the diffusion of a human rights culture may be more difficult than in other places due to the US exceptionalism in human rights. In this respect, Neubeck emphasises the importance of 'translators' within the local administration and how the application and production of human rights is both encouraged and monitored, across different departments and in relation to particular issues.

The second lesson regards the power that human rights have to actually regulate and guide the city. Different chapters of the book suggest how the structure of the city and its politics can limit the capacity of human rights and the right to the city to impose themselves in the city. So, while the Ombudsman in Montreal deals with many issues, recommendations that the police should fall within the legal reach of the Ombudsman have not been followed up (see Frate in this volume). In Eugene some action has been taken to recognise and implement the right to housing and shelter; however, the City Council has left the criminalisation of homelessness untouched and the solutions provided have been 'limited' (see Neubeck in this volume). Finally, in Mexico City, while the Charter for the Right to the City has triggered a process of participation and consensus building involving a variety of actors, this has not impeded the eviction of people from one to another area of the city to make space for the highway project (the Supervía), and the movements that have supported the Charter are now acting towards making it legally enforceable.

An interesting association is made in these three examples between the limits of the human rights city and the right to the city, how these are generated by the prioritisation in local politics of other agendas and principles, and the invocation of the law as an ally towards reinforcing human rights and the right to the city. What is invoked here is the support of the law towards expanding the scope and reach of human rights and the right to the city, while protecting their core content by 'isolating' it from politics. Of course, it seems reasonable to think that it is politics itself that in all cases has kept the law out of the picture. The three examples then raise the obvious question of the role of the law in the co-production of the human rights city and the right to the city and the extent to which their practice should be legalised, in a way that is enabling and not constraining, particularly of discourse. This is, again, a question that has no easy solution, and needs to be solved in and by the practice.

\section{CONCLUSION: FOR A SOCIOLOGY OF THE HUMAN RIGHTS CITY}

Sociology can help cast a light on the different ways in which cities engage the idea of human rights by focusing on the urban practice of these rights and how in this practice human rights acquire meaning and this meaning come to guide urban life. This notion of the human rights city is quite broad and potentially inclusive of a variety of cities, including those who engaged with human rights before a more organised movement of 'human rights cities' emerged. It is a notion that does not preclude the more socio-legal investigation of how international human 
rights are applied by local government (see Oomen in this volume), while refocusing attention on the city as a context in which human rights and their practice is reconstructed (see Graham et al. in this volume) and, as part of this process, human rights are 'urbanised' (see Darling in this volume). Equally open is the possibility that the human rights city might also be about the right to the city, as human rights and the right to the city become connected in practice. In fact, what this chapter suggests is that the right to the city itself is, for some, a human right, and this is maybe the area in which cities are innovating most in the broader practice of human rights. An interesting question will be, then, the extent to which the right to the city will be accepted as a human right in the general practice.

Seen as a practice, we come to realise that there is no inherently true or good human rights city and that meaning depends on who has the power to define and lead the human rights city. In this respect, there are also ethical issues involved in the human rights city, raised by the more general tension between application and inclusion in the practice of human rights (on this see also Goodhart 2008). These issues call into question how actors handle the power that the discourse of human rights gives them: their own assumptions about the meaning of human rights, the extent to which human rights empower and discipline especially those who seem to need them most, how the law supports both empowerment and discipline, and the fact that other local actors may be critical of human rights and eventually prefer alternative patterns towards justice. ${ }^{4}$ These issues should then be considered in the light of the institutional support that the local government provides to the city: how justice and government are balanced one against the other, which impact on what meaning human rights require in the city.

As practice, the inherently political character of the human rights city is exposed, forcing its consideration and analysis within the broader social structure that mediates between the discourse and practice of the human rights city. The question then becomes understanding the broader set of constraints and opportunities within which the urban practice of human rights emerge in different cities of the world, and the extent to which the 'proximity' of cities to the everyday life of human rights can generate a practice of resistance to the harshest forms of neoliberal domination in the city. For this reason it is important to keep an eye on how human rights are constructed, not only in city charters and statements but also, and eventually most importantly, at the level of the work and engagement of the human rights institutions of the city. Equally important is how the law is engaged in the process, with an understanding that powerful actors inside the local government will be more interested in using it against anybody but itself.

\footnotetext{
${ }^{4}$ For example, although gay rights have become popular and fashionable in many cities, especially the 'queer' sector of the broad LGBTQI+ movement remains sceptical of the assimilationist dynamics implied in legal constructions of sexuality (Grigolo 2003). Arguments have been made on these premises about 'virtual equality' (Vaid 1995) and 'against equality' (Conrad 2014).
} 
On the way, actors, especially those more concerned with justice than government, outside and inside government, should remain vigilant as to the compromises that the social, political and economic forces that shape the city will make inevitable. Any negotiation of human rights in the city, including of their own use, should be considered as strategically related to the broader project of the human rights city. Any compromise should be accepted with an understanding of its relation with, and impact on, the local and broader practice of the human rights city.

\section{References}

Chiu, Victoria 2013. 'Vers la "remunicipalisation" du service public d'eau potable en France', Pyramides, 25, http://:pyramides.revues.org/985.

Conrad, Ryan 2014. Against Equality: Queer Revolution Not Mere Inclusion. Edinburgh, Oakland, Baltimore: AK Press.

Fantini, Emanuele 2012. 'Water as Human Right and Commons: Themes and Practices in the Italian Water Movement', Pace Diritti Umani 2: 15-40.

Fung, Archon and Olin Wright, Erik (eds.) 2003. Deepening Democracy: Institutional Innovations in Empowered Participatory Governance (The Real Utopias Project). London, New York: Verso.

Goodale, Mark 2007. 'Introduction: Locating Rights, Envisioning Law Between the Global and the Local', in Goodale and Merry (eds.), The Practice of Human Rights: Tracking Law Between the Global and the Local. Cambridge: Cambridge University Press, pp. 1-38.

Goodhart, Michael 2008. 'Neither Relative nor Universal: A Response to Donnelly', Human Rights Quarterly 30: 183-193.

Grigolo, Michele 2009. 'Human Rights and the City: Anti-Discrimination Laws and Policies in New York and Barcelona', PhD Dissertation, European University Institute.

Grigolo, Michele 2003. 'Sexualities and the ECHR: Introducing the Universal Sexual Legal Subject', European Journal of International Law 14(5): 1023-1044.

Grigolo, Michele 2010. 'Human Rights and Cities: The Barcelona Office for Non-Discrimination and its Work for Migrants', The International Journal of Human Rights 14: 896-914.

Grigolo, Michele 2011. 'Incorporating Cities into the EU Anti-Discrimination Policy: Between Race Discrimination and Migrant Rights', Ethnic and Racial Studies 34: 1751-1769.

Hynes, Patricia, Lamb, Michele, Short, Damien and Waites, Matthew 2010. 'Introduction: Sociology and human rights: confrontations, evasions and new engagements', The International Journal of Human Rights 14(6): 811-832.

Keating, Michael 1991. Comparative Urban Politics: Power and the City in the United States, Canada, Britain, and France. Aldershot: E. Elgar. 
Koenig, Shulamit 2012. 'Foreword: There Is No Other Option!', in Judith Blau and Mark Frezzo (eds.) Sociology and Human Rights: A Bill of Rights for the Twenty-First Century. Thousand Oaks: Pine Forge Press, pp. vii - xi.

Le Galès, Patrick 2002. European Cities: Social Conflict and Governance. New York: Oxford University Press.

Lipsky, Michael 2010. Street-Level Bureaucracy: Dilemmas of the Individual in Public Services. New York: Russell Sage Foundation.

Morris, Lydia 2006. 'A foundation for rights or theories of practice?', in Lydia Morris (ed.) Rights: Sociological Perspectives. London: Routledge, pp.240-252.

O’Byrne, Darren 2012. 'On the Sociology of Human Rights: Theorising the Language-structure of Rights', Sociology 46(5): 829-843.

Oomen, Barbara and Van den Berg, Esther 2014. 'Human Rights Cities: Urban Actors as Pragmatic Idealistic Human Rights Users', Human Rights and International Legal Discourse 8: 160185.

Peterson, Paul E. 1981. City Limits. Chicago: Chicago University Press.

Purcell, Mark 2002. 'Excavating Lefebvre: The Right to the City and Its Urban Politics of the Inhabitant', GeoJournal, 58: 99-108.

Purcell, Mark 2008. Recapturing Democracy: Neoliberalization and the Struggle for Alternative Urban Futures. London: Routledge.

Sala Pala, Valérie 2010. 'Differentialist and Universalist Antidiscrimination Policies on the Ground: How Far They Succeed, Why They Fail: A Comparison Between Britain and France', American Behavioral Scientist 53: 1788-1805.

Smith, Jackie 2015. 'Human Rights City Initiatives as a Peoples Peace Process', paper presented at the ASU Peoples Peace Conference, Arizona State University, Tempe, 16 and 17 April 2015.

Rask Madsen, Mikael 2013. 'Beyond Prescription: Towards a Reflexive Sociology of Human Rights', in Mikael Rask Madsen and Gert Verschraegen (eds.), Making Human Rights Intelligible: Towards a Sociology of Human Rights. Oxford: Hart Publishing, pp. 81-103.

Ruzza, Carlo 2006. 'Human Rights, Anti-Racism and EU Advocacy Coalitions', in Morris (ed.), pp. 111-128.

Stammers, Neil 2009. Human Rights and Social Movements. London: Pluto Press.

Vaid, Urvashi 1995. Virtual Equality: The Mainstreaming of Gay \& Lesbian Liberation. New York, London, Toronto, Sydney, Auckland: Anchor Books. 